
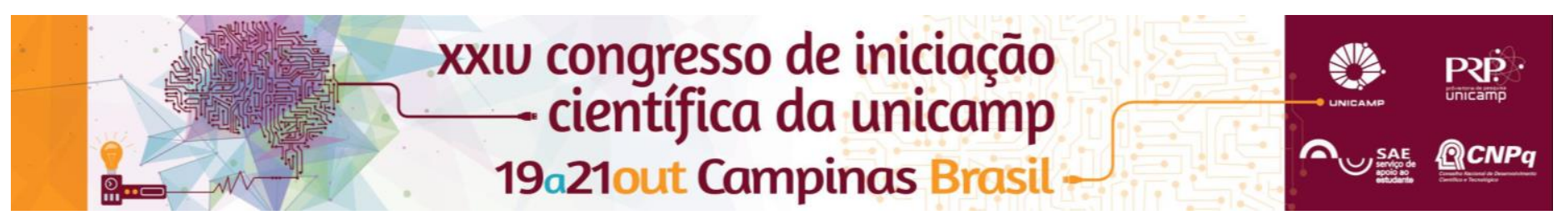

\title{
Automatização do processo de rebitagem para atender normas de segurança
}

\section{Lucas Guarda Cirigliano*}

\section{Resumo}

Esse artigo é um estudo de viabilização do uso de plataformas de prototipagem eletrônica para automatizar um processo de rebitagem e garantir a integridade física do operador atendendo a norma regulamentadora no Brasil para equipamentos de prensagem (NR 12).

Foram feitas pesquisas para definir qual plataforma de prototipagem usar, além de sensores e outros elementos que compõem o comando elétrico do equipamento.

A plataforma selecionada foi o Arduino, que apresentou ser um sistema de controle compacto, de baixo custo, de fácil programação e que cumpre com todas as necessidade requeridas para o acionamento de um equipamento tal como a rebitadeira. Além do acionamento das funções básicas da maquina, essa plataforma se mostrou capaz de ler sensores que serão usados como barreira de segurança separando o homem da zona de perigo (zona de rebitagem) atendendo assim as normas exigidas.

\section{Palavras-chave:}

Rebitadeira, Arduino, norma regulamentadora $n^{\circ} 12$

\section{Introdução}

De acordo com lida, et al (1991), a partir da década de 70 , começou a haver uma mudança de abordagens em segurança do trabalho. Isto resultou da evolução da própria natureza do trabalho humano, com a introdução da automação e a consequente substituição dos processos musculares pelos processos mentais.

A automatização nas indústrias fez com que os acidentes de trabalho se tornassem menos comuns, sendo os responsáveis pela manutenção das máquinas os mais sujeitos a este risco. São nas pequenas e nas mais antigas indústrias que permanecem os problemas tradicionais com segurança do trabalho (VILELA, 2000).

Desta forma, fica claro que com a automatização das indústrias, o uso de micro controlador e Controladores Lógico Programável (CLPs) tornou possível prevenir erros nos equipamentos de forma a proteger quem os opera. Sendo este o foco deste estudo, que é utilizar lógicas computacionais junto a sensores para desenvolver barreiras entre o homem e a maquina a fim de protegê-lo contra qualquer possível falha tanto do equipamento quanto do operador.

\section{Resultados e Discussão}

A pesquisa obteve resultados positivos, pois todos os pontos abordados ao longo da pesquisa foram executados com sucesso. Como exemplo, a utilização do sensor de ultrassom que cumpriu com todas as exigências da qual a norma impõe como requisito para a operação de máquinas de prensagem.

O funcionamento da rebitadeira feita através do micro controlador junto aos componentes cumpriram com o esperado, a máquina obteve mesmo ou melhor desempenho de funcionamento com um comando de menor custo do que usado atualmente.

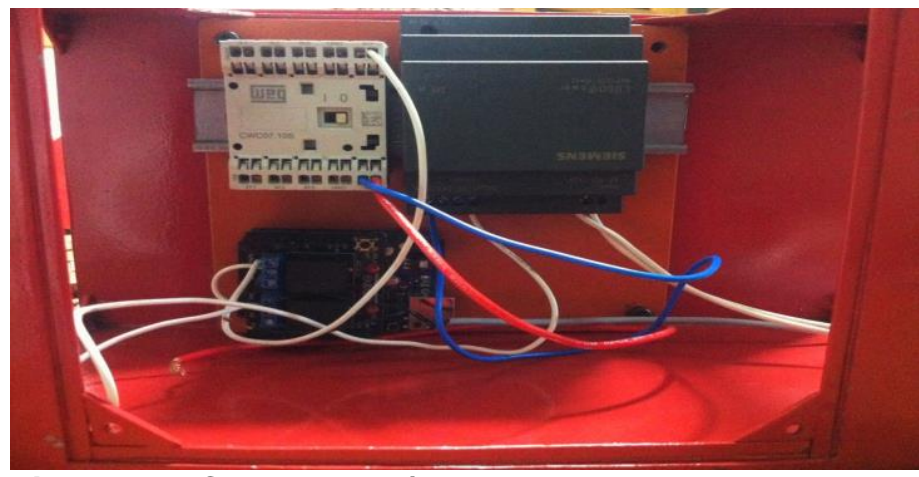

Figura 1. Comando elétrico com micro controlador, contactor e fonte de $24 \mathrm{Vcc}$ para rebitadeira.

\section{Conclusões}

O presente estudo mostrou a eficiência de um equipamento industrial de rebitagem operado por uma plataforma de prototipagem.

O uso de micro controladores tais como o Arduino são ferramentas poderosas para garantir a segurança e aumentar a produtividade em processos industriais que necessitam de equipamentos como rebitadeiras e prensas.

${ }^{1}$ BRASIL. Ministério do trabalho e emprego. Norma Regulamentadora $\mathbf{n}^{\mathbf{0}}$ 12. Disponível em: <http://portal.mte.gov.br/legislacao/normasregulamentadoras-1.htm>. Acesso em: 16 Abr. 2015>.

${ }^{2}$ IIDA, Itiro. Novas abordagens em segurança do trabalho. Prod., São Paulo v. 1, n 2, 63-72, Dec 1991 Disponível em: <http://www.scielo.br/scielo.php?script=sci_arttext\&pid=S01036513199100020 0001\&lng=en\&nrm=iso >. Acesso em: 21 Abr. 2015.

${ }^{3}$ VILELA, Rodolfo. Acidentes do trabalho com máquinas- identificação de riscos e prevenção. Cadernos de saúde do trabalhador. 2000. Disponível em: $<$ http://www.cerest.piracicaba.sp.gov.br/site/images/caderno520segurancae m20maquin1.pdf >. Acesso em: 21 Abr. 2015. 